\title{
Staying in the Game
}

I HAVE BEEN THINKING about the future of libraries, especially what I would call "special collections" or "research" libraries, for much of my career. During this time, technology has played an increasingly significant and positive role in libraries. In recent years as others wrote books about the demise of printed books and the end of the library, I dismissed this view and have been content to believe in a future for libraries that many have labeled as "hybrid." I thought that this hybrid state of books and other printed materials coexisting in libraries alongside digital collections would last a long, long time - at least well into the first half of the 21st century, and surely for longer than I planned to remain active professionally. I thought I did not have to worry about the future.

As it turns out, I was wrong. Special collections libraries, in contrast to circulating, general library collections, may soon be the only kind of library housing significant paper collections. These special collections libraries may become the only game in town for those of us who want access to physical books. I think we are nearing the "tipping point," if we have not already passed it. To quote Malcolm Gladwell, who published the bestseller of that title, "the expression first came into popular use in the 1970s to describe the flight to the suburbs of whites living in the older cities of the American Northeast. When the number of incoming African Americans in a particular neighborhood reached a certain point—20 percent, say—sociologists observed that the community would 'tip': most of the remaining whites would leave immediately. The Tipping Point is the moment of critical mass, the threshold, the boiling point." I like to think of my childhood in Michigan to understand what the "tipping point" is. I would go to bed listening to icy rain hit my bedroom window. In the morning I would look out to a wonderland covered in snow. The difference between 33 degrees Fahrenheit and 32 degrees Fahrenheit seems so small, and yet,

1. Malcolm Gladwell, The Tipping Point: How Little Things Can Make a Big Difference (Boston: Little, Brown, 2000), p. 12. 
it is so dramatic. The academic research library, as we have known it in the second half of the 20th century is changing radically and rapidly. Non-rare print collections are fast becoming a thing of the past. This seems to be caused by two forces at work in parallel. The first is Google, in both its Google Scholar (which Google describes as "a simple way to broadly search for scholarly literature") and Google Print ("Google Book Search") manifestations, as well as the many copycats of Google. The second is the demise of university presses and the scholarly monograph. What is my evidence? I have been accumulating a clipping file for over a year now, which includes some of the following articles.

1. In the International Herald Tribune, Business $\&$ Technology Innovation section (Wednesday, December 15, 2004), an article by John Markoff and Edward Wyatt, "Google Turns a New Page in Library Project," appeared. The opening paragraphs were these: "Google, the operator of the world's most popular Internet search service announced an agreement Tuesday with Oxford University and some of the leading U.S. research libraries to begin converting their holdings into digital files that would be freely searchable over the Web.

"It may be only a step on a long road toward the long-predicted global virtual library. But the collaboration of Google and research institutions that also include Harvard, the University of Michigan, Stanford and the New York Public Library is a major stride in an ambitious Internet effort by various parties."

Towards the end of this article, the authors state, "the trend toward online libraries and virtual card catalogs is one that already has book publishers scrambling to respond. At least a dozen major publishing companies have already entered ventures with Google and Amazon that allow users to search the text of copyrighted books online and read excerpts."

Although this story had been reprinted from The New York Times, I found it significant that the first announcement of the Google Print project then showed up immediately in the International Herald Tribune, a newspaper available to the English reading community throughout the UK, Europe, the Americas, and Asia.

I was oblivious to much that appeared in the press in January and February of 2005. Then I spent the month of March 2005 in Paris where I asked French librarians what their thoughts were about Google Print. They were angered by it because they believed that only books in English would be digitized. I told them that the libraries Google made agreements with all had significant holdings in languages other than English. 
2. Then, in the May 2 and 9, 2005 issue of The New Republic, David A. Bell's article, "The Bookless Future: What the Internet Is Doing to Scholarship," appeared. This is a long piece in which Bell describes his experience reading an entire scholarly monograph online. On the first page he argues, "But the Internet revolution is soon likely to become much more controversial, and for a simple reason: scholarship is fast moving toward a bookless future. Physical books are expensive to produce, and they are easily damaged or stolen. Shelf space costs money to build. Shelving and re-shelving books costs more. Stacks have to be kept at the appropriate temperature and humidity; they need to be lit, cleaned, inspected, and insured. Why, it is already being asked, should universities pay large sums to preserve and circulate physical books if copies exist online?"

He goes on to talk about the scholarly monograph and says, "But today specialized books of this sort [the scholarly monograph] are a distinctly endangered species. Their main purchasers - university libraries— have far less money to spend on these items than they once did. Computerized catalogues, subscription content, hugely expensive scientific journals, exploding storage costs: all these demands are putting tremendous pressure on budgets that are often already flat or declining. In response, libraries have cut back purchases or have started to form consortia with their neighbors, so that now only one research library in a given region may buy a particular book. As a result, specialized academic titles often sell as few as two hundred copies [emphasis mine. I would characterize this as a limited edition. Is it not?!], and university presses lose an average of more than $\$ 10,000$ on each. The presses have cut back in turn, particularly in the more arcane precincts of scholarship. They are also passing the cost pressures on to those authors they do accept; it is becoming routine in some fields for university presses to demand subsidies of $\$ 5,000$ or more to publish a book, and to insist on strict limits on length. In some fields, the printed academic monograph is dangerously close to extinction" [emphasis mine].

3. Saturday, May 14, 2005, may have been a quiet news day at The New York Times. As I was reading my copy over breakfast that morning, I flipped to the lower half of the front page and noticed this headline: "College Libraries Set Aside Books in a Digital Age." The article was by Ralph Blumenthal with the dateline Houston, May 13. It begins: "Students attending the University of Texas will find something missing from the undergraduate library this fall. Books. By mid-July, the university says almost all of the library's 90,000 volumes will be dispersed to other university collections to clear space for a 24 -hour electronic information commons, a fast-spreading phenomenon that is transforming research and study on campuses around the country." It goes on: "Students at Texas, interviewed as they studied or lounged at the library tables, said that they would welcome extra computer space ..." When I discussed this article with Richard Oram, Librarian of the University of Texas 
Ransom Humanities Research Center (HRC), he said the article really had nothing new to report. He indicated that most of the books had been removed from the undergraduate library ages ago. After learning this, I realized that the big news was that this little-known fact was being reported for the first time on the front page of The New York Times. To paraphrase Malcolm Gladwell in The Tipping Point, I saw this as an example of "how a little thing might make a big difference."

4. Later in May, I noticed an article by Jeffrey R. Young in The Chronicle of Higher Education (May 20, 2005) with the title "100 Colleges Sign Up with Google to Speed Access to Library Resources." It opened with these words: "More than 100 colleges and universities have arranged to give people using the Google Scholar search engine on their campuses more direct access to library materials. Google Scholar is a free tool [emphasis mine] that searches scholarly materials on the Web and in academic databases. The new arrangements essentially let Google know which online databases the colleges subscribe to, as well as what is in their library catalogs, so that Google Scholar can point users to those campus resources. As a result, at participating colleges, a Google Scholar search result now includes direct links to online copies of works if the institution has purchased online access." Seeing this article reminded me that the business model has changed. The old business model had vendors selling or leasing information to libraries. Google does not try to sell information. Instead, Google's new business model is to sell advertisements and provide information to anyone who has Internet access for free.

5. In the June/July 2005 issue of American Libraries, this headline caught my eye: “Europe Unites to Create Its Own Digital Library.” Just as I might have predicted, it begins: "In the wake of France's call for European nations to make their library collections available on the internet to counter a perceived English-language dominance, six European leaders have offered a proposal for what they called a 'European digital library.' " Later in the article I found that "The Google Print Library Project's website states it is not limiting its scanning to books in English ..." and "In fact, Google representatives met in Paris May 3 with National Library officials to discuss potential collaborations." Of course, "Google Europe” was born.

6. The university press scene was again scrutinized by John B. Thompson in The Chronicle of Higher Education, June 17, 2005 issue. His lengthy article entitled "Survival Strategies for Academic Publishing" begins with these words: "The new millennium is proving to be a testing time for academic publishers. Whereas the 'long decade' from the early 1980 s to 2000 was a buoyant period for many presses in the field of academic publishing, including many university presses, the period since 2001 has brought a rude awakening. Growth rates of university presses have fallen to the lowest levels in many years, returns from booksellers have reached unprec- 
edented heights, and some university presses have been faced with the prospect of imminent closure." Further along Thompson states, "So if we want to understand the problems faced by academic publishers today, we have to reconstruct the logics of the fields to which they belong. Only a deeper analysis of that kind will enable us to see that those problems are not temporary and superficial disturbances in an otherwise smoothly operating system, but rather are symptomatic of a profound structural transformation. ... [The monograph] has undergone a process of continuous decline since the 1970s. Experiences vary from publisher to publisher, but the overall pattern is indisputable. In the 1970s, scholarly publishers in both the United States and Britain would commonly print between 2,000 and 3,000 hardback copies of a monograph and expect to sell a substantial proportion (if not all) of them. ... Today most scholarly publishers find that the total sales of hardback-only monographs are often as low as 400 to 500 copies worldwide." (I might add again that with print runs this low these are limited editions.)

If, as my evidence suggests, research libraries are divesting themselves of non-rare printed materials, and if publishers are no longer publishing scholarly monographs in large editions or not publishing them at all, then where does this leave research libraries with their vast collections of rare materials, aka special collections? I believe it means that the only game in town is these rare and unique materials and the communities of scholars that can be built around them. And if the rare and unique are the only game in town for research libraries, does that mean we can continue to do business as usual? I think not. We are still at risk. We are still at risk because possibly, for the first time in human history, research libraries have a competitor.

At the RLG Annual Meeting in April 2005, I heard a talk entitled "Long Overdue: Rethinking the Librarian's Role in a Post-Google World” by Michael Schrage, Co-Director of the E-Markets Initiative, MIT Media Lab. Here is the opening of his talk: ${ }^{2}$

Good morning. It's a pleasure to be able to stand here and say to you, honestly, sincerely and from the bottom of my heart: I love libraries. I use them a lot. I've used them in Europe, Asia and all over America. I've even been to Bill Gates's personal library in Seattle and schmoozed his archivist.

Libraries and Archives have an enormously positive influence on my life. They've made my books and my papers and my research better. I'm also the kind of guy who likes to browse through stacks and see what serendipity can do in provoking new connections for me.

2. I received permission from Mr. Schrage to quote liberally from his talk in a brief e-mail exchange that took roughly forty-five minutes from the time I sent him my initial request to the time I had his permission. 
As a rule, the librarians and archivists I work with have been helpful and professional, if not a little overwhelmed. Research libraries and archives have played an indispensable role in making me more professionally effective. I'm grateful. So, for reasons personal, professional and cultural, I believe libraries are astonishingly important institutions that need to survive and they deserve the opportunity to become an even more important part of thinking people's lives.

So have I done enough sucking up? Good. Because there's trouble in paradise. I have a confession to make: I've been cheating on you.

It's not that the other information sources out there are better looking or in better shape. It's not that I don't care about you anymore or care about our relationship. And you know I care about the kids-because, really, children are our future and all of that ... Frankly, it's not even that I'm tired of constantly hearing you moan about how much more vibrant and exciting you'd be if only you had more of my money.

The thing is, you just don't take real-time responsiveness as seriously as I do. You like to take your time-which means you like to take my time. Patience may be a virtue but sloth is one of the seven deadly sins. I need you to respect my desire for greater speed in response and I need you to respect my need for more convenience. Is that so wrong? Is that so selfish?

So, yes, I'm spending more time with Google. It's fast and it's quick in a way that you never are. Do I always get the best answers or pointers I need? No-but they're almost always "good enough"-and, you know, some times "good enough" is pretty damn good. Even at MIT—and especially at Harvard.

So when that inter-library loan for that out-of-print British book on "intelligence" was going to take over three weeks to get to MIT and even then would require me to review it in the special reserve section? Well, yes, I hopped onto Bibliofind and bought it from a bookshop in Australia and had it shipped to me-all pristine and all mine-in under ten days for under $\$ 50$. That's right. I'm not ashamed. It was worth it.

Let's be honest: you ALWAYS make me come to you. I always have to go to your place. You're not one to compromise. Your place; your rules. You like controlling access. Don't get me wrong: you're very good and I love you. But we have to rethink what we both want out of this relationship in the long-term. 
I'll stop there. Michael goes on to make some very important points. He argues that libraries have been too good at collaboration, and that by being collaborative they have not been competitive. He believes that if libraries were more competitive, they would be more innovative. And finally, he argues, it is innovation that will help libraries stay relevant.

In contrast to Michael Schrage's desire for speed and his acceptance of "good enough," Thomas Mann put forward a challenge in his American Libraries article that appeared in the August 2005 issue under the title, "Google Print vs. Onsite Collections." ${ }^{\prime 3}$ The subtitle boasted, "Don't send your paper copies off to remote storage just yet." In this article Mann, a reference librarian at the Library of Congress for twenty-four years, describes browsing 186 volumes in LC's closed stacks for a graduate student trying to verify some information regarding the French Symbolist poet Paul Valéry's connection to the Dreyfus affair of the 1890s. Mann claimed that a Google search produced over 3,500 hits of "chaff." I searched a combination of three words_-"Valery," "Dreyfus," and "case" - in Google Print and in less than five minutes I found two secondary texts with footnotes that verified the information being sought. These texts were on the first screen of the twenty screens that I retrieved and within the first six titles listed. Mann never reveals just how long his browsing of six shelves of books took. I would say that the Google search I did was "good enough." A 2004 nationwide survey of more than 2,300 faculty members, reported in The Chronicle of Higher Education last August, stated: "Browsing library stacks could soon be seen as old-fashioned. Most of the professors surveyed, 83 percent, said they spent less time in the library now than they did before they had Internet access." ${ }^{\prime 4}$ think this is exactly Michael Schrage's point. What research libraries need to do is become more competitive.

But how can libraries be more competitive? How can they remain vital? Research libraries need to trumpet to the world their special and unique qualities and collections to show they offer what Google cannot offer. We should leverage intellectual property rights in order to replace photocopies of rare materials requested for study purposes with digital copies on demand. Insofar as copyright law will allow, research libraries should make this an "industry standard." All deeds of gift and acquisitions contracts for materials covered by copyright law should include language allowing libraries to make digital copies for readers' study purposes regardless of who retains the intellectual property rights for the long term. Librarians should continue to lobby for updated fair use legislation to cover digital copies, especially for copies from orphan works.

3. Thomas Mann, "Google Print vs. Onsite Collections: Don't Send Your Paper Copies Off to Remote Storage Just Yet,” American Libraries (August 2005): 45-46.

4. Jeffrey R. Young, "Professors Give Mixed Reviews of Internet's Educational Impact," Chronicle of Higher Education 51:49 (August 12, 2005): A32. 
We should accept "good enough" cataloging access (some might say, "quick and dirty") to make hidden or invisible collections available and get them out of the "backroom."

We should serve all comers. New audiences with interests in rare materials are emerging. They may be artists, realtors, journalists, writers, homeowners, undergraduates, and even high school students.

We should build a community within the walls of the research library. We can do this through scholarship programs, research grants, and public programs.

Finally, perhaps we need to do more marketing. Isn't that what competitors must do in the larger world?

I continue to monitor the news. Of course, there are the many reports of litigation between Google and publishers. This litigation has only slowed Google down in its inevitable march toward making the comprehensive digital library available free of charge on the Internet. One advertisement offering students a digital "Research Assistant" is my personal favorite. I first noticed it in the New York Times in March. The Times continues to run it regularly. It is a reminder that daily newspapers must also reinvent themselves in the era of the blog.

In summary, first of all, I believe a tipping point has occurred, and the research library as we know it is changing now more rapidly than ever before. Second, even research libraries of special collections materials are at risk of becoming irrelevant. And finally, while unique materials and a stimulating intellectual community are likely to continue to attract readers, research libraries must still find other ways to become more competitive in order to remain relevant. 